Magyar Honvédség Egészségügyi Központ ${ }^{1}$,

Magyar Honvédség Egészségügyi Központ Parancsnok², Magyar Honvédség Parancsnoksága Haderőtervezési Csoportfönökség ${ }^{3}$

\title{
(Gondolatok a katonai alkalmasságról) Gondolatok a katonai alkalmasság múltjáról és jelenéről
}

\author{
Prof. Dr. Sandra Sándor ${ }^{1}$ ny. orvos ezredes, $\mathrm{PhD}$, \\ Kun Szabó István ${ }^{2}$ vezérörnagy, \\ Dr. Sticz László ${ }^{3}$ dandártábornok, PhD
}

Kulcsszavak: globalizáció, katonai alkalmasság, biztonságpolitika, vizsgálati rendszer

\begin{abstract}
A felgyorsuló és összetetté váló politikai, gazdasági, társadalmi és demográfiai folyamatok kihatnak a haderő felkészítésére és fejlesztésére. A nemzeti haderő legfontosabb és egyben elengedhetetlen pillérei maguk a katonák, akiknek állományba vételét, felkészítését, kiképzését mindenképpen meg kell, hogy előzze egy mindenre kiterjedő alkalmasságvizsgálati folyamat.
\end{abstract}

A jövő hadereje ennek megfelelöen, egy korszerüen felszerelt, magasfokú mobilitással és reagáló képességgel rendelkező szervezeti egység, amely képes az információs és döntési fölény birtokában egy időben, több helyszínen történő azonnali, gyors és hatékony beavatkozásra, műveletek végrehajtására, akár nemzetközi keretek között is.

A hadmüveleti és szolgálati feladatokban egységes szervként tud fellépni a hivatásos, szerződéses és önkéntes tartalékos állomány.

A XXI. századi biztonságpolitikai követelmények létfontosságú elemként ke- zelik a katonai alkalmasság kérdését, hiszen az ország védelme, ill. a NATO-ban vállalt kötelezettségeink magas szintü elvárást támasztanak katonáinkkal szemben. A „megfelelő embert a megfelelő feladatra" elképzelés a fronton született, ennek megfelelően az alkalmasságra vonatkozó vizsgálatok, azok hangsúlyai folyamatosan változtak. Hazánkban is mindig kulcskérdés volt a honvédelem ügye és az abban szolgálatot teljesíto emberek sorsa. Ennek értelmében a sorozási alkalmassági vizsgálati rendszer az évszázadok alatt többszörösen megújult, mégis folyamatos kiigazítást igényel. 
„Ím mi állapotunk, látjátok, miben van: Erös birodalmunk henyélést nem kíván, $A z$ mit karddal nyertünk, nem tartja meg Déván; Fegyvert s erös vitézt birodalom kíván."

Az új évezred küszöbén az élet minden területén meghatározó befolyással bíró globális verseny az ország biztonságának zálogául szolgáló hadsereggel szemben is komoly elvárásokat támaszt. $\mathrm{Ez}$ megmutatkozik a magas szakmai színvonal, az állomány tagjaival szemben elvárt követelmények tekintetében. Bár a katonai szervezet, mint intézmény, mindig felismerte az emberi tényező meghatározó voltát, mégis csak az elmúlt század második felétól kapott hangsúlyosabb szerepet.

Minden ember önálló személyiség, többé-kevésbé sajátos adottságokkal, személyiségi vonásokkal és viselkedési formákkal. Az alkalmasság vizsgálata minden esetben az egész személyre irányul, hogy képes lesz-e a neki kiadott feladat ellátására. Esetleg rendelkezik-e olyan jellemzőkkel, amelyek egyértelmüen kizárják vagy lehetetlenné teszik a sikeres szolgálati feladatok elvégzésére. A honvéd egészségügy a feladatok végrehajtása elött javaslatokat tehet, hogy a kiképzést miként tehetjük hatékonyabbá. A katonai alapkiképzés a katonai pálya szocializációja folyamán meghatározó szerepet játszik. Mindebből következik, hogy az alkalmasság csak potenciálisan állapítható meg, minden a gyakorlatban dől el, azaz hogy a katona az elvárásoknak megfelelően hajtja-e végre a feladatot.

A fegyveres erők fejlesztése, személyi állomány biztosításának kérdése, a hidegháborús szembenállás megszűnését követően csaknem minden európai országban napirendre került. Egyik oldalon a túlméretezett haderő, míg a má- sik oldalon az új típusú haderő felállításának problémaköre állt, annak személyi állományával, formai követelményének minden nehézségével.

Míg a XX. század második felében a Magyar Néphadseregben is a szovjet hatás érvényesült, a 90-es évektől megfigyelhető némi változás a fizikai követelmények megítélésében. Bár jó katonának az számított, aki jól teljesített a sportversenyeken, mégsem távolították el a szervezetből a gyengén teljesítőket.

A rendszerváltást követően a korábban szervezett, nagy tömegeket megmozgató sportélet jelentősége hátrább szorult és felváltotta egy minden tekintetben megreformált alkalmassági vizsgálat. Már nemcsak fizikai és mentálhigiénés felkészültséget vártak el, a NATO csatlakozást követően a nyelvtudás is meghatározó szemponttá vált a katona megítélésében. Az amerikai mintát átvéve a 12/1997. (V. 16.) HM rendelet szabályozta a hivatásos és szerződéses katonák egészségi, pszichikai és fizikai alkalmasságát.

Ahogy emelkedett a katonákkal szemben támasztott követelmény, úgy változtatták képességeik felmérésének metódusát is. A magyar békefenntartói szerepvállalástól - amely a 19. század végéig nyúlik vissza - eljutottunk a multinacionális szerepvállalásig, ahol a válságreagáló műveletek során egyre újabb elemek jelennek meg a katonai tevékenységbe beépítve.

Néhány tragikus kimenetelü hadiesemény felhívta a figyelmet a pszichikai tényezők fontosságára is. A hosszabb békeidőszakot követően a háborús övezetben bevetett hadsereg által szerzett tapasztalatok is azt igazolják, hogy sok esetben az ismeretlenre való felkészítés, illetve annak kezelése nyújthat némi biztosítékot a katona számára. Az Osztrák- 
Magyar Monarchia utolsó haditapasztalatokat nyújtó háborúja 1866-ban zajlott, ennek igen tragikus következményeit tapasztalhattuk meg az I. világháborúban.

Az elvárás, hogy a „megfelelő embert a megfelelö feladatra" megtalálják, nem új keletű kívánalom. Már az ösemberek is a képességüknek megfelelően osztották szét feladataikat egymás között. A kezdeti törzsi szerveződésükben is tisztában voltak azzal, hogy, csak azokat vihetik vadászatra, illetve háborúba, akik bátrak, erősek, rátermettek, ügyesek és kitartóak. Ezt a képességet különböző avatási próbákon bizonyíthatták.

Ismereteink szerint Gedeon - héberül Gideon (,kardforgató) Joás fia, a bírák egyike a Bibliában - hajtotta végre az első katonai alkalmassági vizsgálatot, mégpedig a Tóra rendelkezése szerint, némileg a saját módszerével kiegészítve. Gideon hadjáratának lényege: az Úr túl nagynak találta a seregét, $s$ megparancsolta neki, hogy csökkentse a létszámot, másképp Izrael azzal dicsekednék, hogy a maga erejéből győzött. Először is kihirdették, hogy aki fél, az menjen haza.

„És szóljanak a tisztek a néphez, és mondják: Van-e itt olyan ember, aki fél, és csüggedt szivü? Menjen és térjen vissza házába, ne csüggessze el testvéreinek szívét a magáéhoz hasonlóan!'”

A megmaradt tízezer is soknak tünt, ezért az Ưr utasítására csak azt a háromszázat tartotta meg, akik egy tó partjára érve nem térdeltek le a vízhez, hanem lehajolva kutya módjára lefetyeltek.

„Tanulj, fiam, tülem isteni félelmet, Tanulj fáradságot s kemény vitézséget; Mert kell tenéked is követned engemet, Sokatjárnod s fáradnod, veritékezned."

Az alkalmasságra vonatkozó vizsgálatok koronként változtak. Az ókori tár- sadalom a közösségi munkára alkalmatlan egyéneket nem, vagy csak nehezen fogadta el. Hüen tükrözte ezt a spártai thaigetoszi módszer. A katonaállamban, elsősorban az egészségeseket illette meg az élethez való jog, tehát csak az maradhatott életben, aki katonáskodhatott, azaz védte az államot. A jó fizikai állapot tehát létfontosságú volt. A klasszikus görög testkultúra jelentőségét nincs olyan, aki nem ismerné, ha másért nem, a négyévenként megrendezésre kerülő olimpiai játékok miatt.

A római katona még a mainál is szigorúbb, keményebb kiképzésben részesült. Mai szemmel is hatalmas távolságokat járt be és embert próbáló feladatokat kellett kiállnia. A gyalogosan menetelő katona a saját fegyverén kívül többnapi élelmet is magával vitte - csak a táborveréshez szükséges eszközök mellett majdnem harminckilónyi teher nyomta a vállát, miközben magas hegyeken, szük hágókon vagy éppen mocsarakon kelt át. Ráadásul az éghajlati viszonyok sem mindig kedveztek az itáliai meleghez szokott katonáknak.

A római katonák még békeidőben sem pihentek. Kő táboraikat, az azokat összekötő utakat a római birodalomban és a határokon maguk építették, amelyek minőségéröl akár magunk is meggyőződhetünk. A hadiutakhoz szükséges köveket a közeli bányákból ők fejtették, a téglát is ők égették.

Későbbiekben a katonai táborok kiképzési alapelemei között jelentek meg az ilyen és ehhez hasonló módszerek. A feudalizmusban már megfelelő fizikai erőnléttel és mozgásszervi alkalmassággal kellett rendelkezniük azoknak, akik harci fegyvereket öltöttek magukra. A lovagkori harcászati feladatokat pedig magas fokú fizikai követelmények teljesítése révén lehetett csak végrehajtani. 
A magyar középkori államszervezet katonai védelmi elve is a hadseregállítás volt. Az állandó és fizetett hadtestek megjelenése elött a szabad, illetve a nem teljes szabadságot élvező rétegek, majd a nemesek alapvető és legfontosabb feladata volt a teljesen vagy részben saját költségükön való hadba lépés. Minden egyes hadba vonulás alkalmat kínált a királynak arra, hogy lemérhesse alattvalói lojalitását, harckészségét és vezérei alkalmasságát az általuk betöltött posztra.

A résztvevők számára pedig a lehetőségek bőséges tárházát kínálta a hadakozás. Az 1278. évi morvamezei csataleírás szerint:

„Négy sereget formált a hadából, ezek közül kettöt a magyarok alkottak. Trencséni Máté és István vértesi gróf vezérletével a két sereg elejétöl a végéig ott forgott az ütközetben."

„Olyan fürgeséggel forgolódtak a csatában, mintha csak Franciahonban tanulták volna a harc fortélyait. S ha akadna bárki, aki azt vetné szemükre, hogy nem kitartók és állhatatosak fegyverben, a höség és csata pora közepette, bizony azt kellene mondani, hogy tudnak sváb módra küzdeni, ha megfelelöen felszerelik magukat lóval és páncéllal." 2

Zrínyi Miklós hadvezér és író elsőként írta le, hogy mit vár a magyar katonáktól.

„A katonasághoz kiválasztandó ifjú legyen tehát élénk szemü, egyenes fejtartású, széles mellü, izmos vállú; erös ujjai,

1 Az Osztrák-Magyar Monarchia idején a magyar katonák a közös hadsereg tagjaként a világ több pontján igyekeztek megakadályozni a konfliktusok kialakulását, ill. elterjedését: pl. 1897-ban Kréta szigetén. (Szenes Zoltán: A békefenntartás hatása a magyar haderőre, Hadtudomány 2006/3.) Osztrák rímeskrónika: Forrás: Múlt-kor/ Rubicon, 1995/5

2 Zrínyi M.: Ne bántsd a magyart! Az török áfium ellen való orvosság. hosszú karjai, kis hasa, vékony lábszárai, fölösleges hússal nem terhelt lábikrái és lábai legyenek, vagyis olyanok, amelyeket erös inak mozgatnak. Ha ezeket a jeleket az újoncban megtaláltad, ne sokat törödj a testmagassággal; a katonák inkább erösek legyenek, mint nagyok. Most még az van hátra, hogy kutassuk, milyen mesterségü újoncokat vegyünk fel, s milyeneket utasitsunk el."3

A francia forradalom a szabadság, egyenlőség eszméi alapján lehetőséget és lendületet adott a foglalkozások szabad választási lehetőségeinek. A foglalkozási betegségek medicinájának, az ipari orvostudománynak. Megalapozását Bernardio Ramazzini olasz profeszszor nevéhez kötjük, aki a felgyülemlett adatokat tudományosan rendszerezte és ezen ismereteit 1700-ban „De morbis artificun diatriba" címen adta közre.

A kapitalizmus gazdasági értékszerüsége, a technikai forradalom és az urbanizáció a természetes testmozgásokat háttérbe szorította, amivel együtt járt az úgynevezett hypokinetikus szindróma megjelenése is. Magyarországon is nagy hangsúlyt fektettek ezért a megfelelő kiválasztásra, már a hadapródok esetében is. A szigorú többnapos felvételi vizsga után, azokat a pályázókat vették föl a hadapródiskola I. évfolyamába, akik a polgári gimnázium IV. osztályát (a mai általános iskola 8. osztályának felel meg) sikerrel elvégezték, illetve az alreáliskolát sikeresen befejezték. Felvételi követelmény volt, hogy a pályázó, a lakhelyéhez legközelebb eső honvéd helyőrségi kórház vizsgálatai alapján testi alkalmasságát és a katonai nevelésre való ráter-

3 Gál A.: Armis et litteris - A pécsi m.kir.: Zrínyi Miklós honvéd gyalogsági hadapródiskola történetéből 1898-1944. (http://mek.oszk.hu/04900/04967/html) 
mettségét, orvosi véleménnyel igazolja, valamint a tanév kezdetén a 14. életévét már töltse be, de a 16. életévét még ne haladja meg. A dualizmus kori Magyarországon a „1868. évi XLI. Törvénycikk a honvédseregröl" vezette be a sorozott hadsereget, amely 136 évig maradt fenn.

Az első világháború idején és azt követően a férfi lakosság hiánya illetve a nők megjelenése a munka világában, valamint a megsokasodott hadirokkant lehetséges munkába helyezése szükségessé tette a pályaválasztási tanácsadás, a foglalkozásra való alkalmassági vizsgálat kialakulását és fejlődését. Magyarországon 1906-ban már müködött pályaválasztási tanácsadó. 1914-ben az első világháború miatt jelentős létszámban kellett katonákat sorozni, így a hadseregnél is szükségszerűvé vált, hogy értékelni tudják az ismeretlen, képzetlen katonák lehetőségeit és képességeit.

1917-ben az USA belépett a háborúba és a kanadai tapasztalatokat alapul véve kidolgoztak egy vizsgálati eljárást az alkalmatlanok kiszürésére és e vizsgálati eredmények révén osztották be az alkalmasokat a különböző fegyvernemekbe.

A vietnami háborút követően az Egyesült Államokban a rendkívül alacsony társadalmi támogatottság hatására kénytelenek voltak radikálisan csökkenteni a haderő létszámát és 1973 júliusában ismét felfüggesztették az általános hadkötelezettséget. Tekintettel arra, hogy a toborzás hatására a népszerüségét vesztett hadseregbe többnyire alacsony iskolázottságú fiatalok jelentkeztek, a hivatásosok illetve tovább szolgálni kívánó hadkötelesek biztosították a hadsereg alapját. Ezek a katonák legalább megfeleltek az akkori, nem túl szigorú követelményrendszernek. Mára az infrastruktúra és a személyi juttatások rendszerének fejlesztésével a minőségi mutatók fellendülése figyelhető meg a személyi állományban. A szolgálatba lépők inspirálási eszközeivel együtt növelték a belépőkkel szemben támasztott követelményeket is, amelynek következtében jelentősen javult azok iskolázottsága is. A felvételi eljárás során támasztott elméleti és fizikai jellegű követelményeket is egyre magasabb hatásfokkal teljesítették. Pl. „minőségi” újoncnak számított (illetve mai is) az, aki érettségivel rendelkezik és a felvételi teszt eredményessége legalább 50\%-os.

Magyarország történetében a honvédelem ügye mindig is kulcskérdés volt. A honvédelem újkori jogi értelmezését az 1848. évi XXI. törvénycikktől számíthatjuk. A magyar hadsereg vezetöi szükségesnek tartották az I. világháború után az alkalmassági vizsgálatok elvégzését a katonajelölteknél. Létrehoztak egy képességvizsgáló intézetet, ahol a katonai alkalmassági és fegyvernemi alkalmasságot vizsgálták. A II. világháború után a Néphadseregben szinte mindenki alkalmas volt sorkatonai szolgálatra. Az akkori vezetőket nem érdekelte, ha kisebb egészségi károsodásokat okozott a katonai szolgálat. Az utóbbi években bekövetkezett társadalmi, jogi és gazdasági változásokhoz alkalmazkodva, határozott igényként fogalmazódott meg az, hogy a katonai alkalmassági vizsgálatok önálló intézetben professzionális módon valósuljanak meg. Ennek szellemében a Magyar Honvédség Egészségügyi Alkalmasság vizsgáló Intézetét 1992 júliusában hozták létre.

\section{Az alkalmassági vizsgálat legfőbb célja}

- szürjék ki az alkalmatlan személyeket,

- állítsanak fel alkalmassági kritériumokat a katona egészségi, pszichiát- 
riai és fizikai alkalmassági vizsgálatának alapkövetelményeihez,

- pontosítsák a megfelelő fegyvernemi és beosztási kritériumokat.

A Nemzeti Haderő alaprendeltetése a haza katonai védelme, illetve a szövetségi rendszeren belül a ráháruló nemzetközi missziókban való részvételek. Az újonnan kiválasztott katona, aki ezt hivatásaként szeretné végezni, megismerkedik egy új életmóddal, ennek minden nehézségével, szokatlanságával. A katonai szocializáció folyamán elsajátítja az adott szakmai elvárásokat, újfajta viselkedési módot, szerepet, az egymáshoz való viszonyulási formákat, értékeket, technikai ismereteket, amelyekre későbbiekben a katonai pálya gyakorlása folyamán szüksége van. Megtapasztalja, hogy mit is jelent ez a szervezet tagjának lenni.

$\mathrm{Az}$ új társadalmi és politikai kihívások a haderővel és az egészségüggyel szemben eddig ismeretlen elvárásokat támasztanak, ugyanakkor egyre több pénzt, időt és energiát igényelnek ezek végrehajtása. A kockázatok mértéke és száma folyamatosan változik a szolgálati feladatok és a hely függvényében. Egyes kockázati tényezők emelkednek, mások csökkennek. Az elmúlt évtizedekben már különböző földrajzi környezetben is bevetik a katonákat, igen rövid felkészítést követően. Ezeken a területeken alig vagy eddig nem ismert egészégkárosító tényezők is megjelenhetnek, ezáltal a pszichoszociális tényezők szinte állandósult egészségügyi károsító tényezőkké válnak.

A XXI. század biztonsági kihívásainak megfelelően a katonák kiképzési és felszerelési feladatai is egyre jobban specializálódnak. Minden egyes katona nélkülözhetetlen a maga területén. Ez azt is jelenti, hogy egy-egy különlegesen kiképzett személy egyre kevésbé pótolha- tó. Ebből következően különösen fontos, hogy a katona olyan fegyvernemi szolgálatot vállaljon, amelyre megfelelő élettani sajátosságokkal rendelkezik, egészsége és testi épsége várhatóan nem károsodik a szolgálat folyamán. Ezért a katona-egészségügy legfontosabb feladata a haderőállomány alkalmassági vizsgálata, állományának szűrése és egészségügyi felkészítése a különböző feladatok végrehajtására.

Egyes beosztásoknál tudományos igények alapján kell a pálya profilját meghatározni. A katonai alkalmasság egy dinamikus probléma és speciális kérdés a fegyvernemi alkalmasság is. A szakbeosztásokra is vizsgálni kell az egyént. A korszerü mozgásszervi alkalmassági vizsgálat az egész szervezetet, mint egységet szemléli. A mai teljesítmény centrikus világban az alkalmassági vizsgálatok hatékonysága sok esetben rövid idő alatt kifejezetten magas szintü orvosi szakmai minőségi munkát követel meg. A teljesítmény vizsgálatok esetén az igénybevételi indikátor paraméterek egyre jobban bövülnek, egy sor egyéb ergonómiai paraméterrel, amivel az állóképességet és fáradtságot is értékelni lehet.

Megjelentették ezért a különböző szakutasításokat, amelyek elöírták az alkalmassági vizsgálatok elvégzési rendjét. A későbbiekben az Eü/18. és Eti. 27-es szakutasítások - amelyek az egészségügyi alkalmassági vizsgálatokat szabályozták - nagy segítséget nyújtottak az alkalmassági vizsgálatokat végző orvosoknak, de az idő haladtával az orvostudomány fejlődésétől ezek az utasítások lemaradtak.

A továbbiakban már a jogi hierarchia magasabb szintjén tanulmányozták az elvégzendő feladatokat a következő rendezőelv szerint: 
- A 7/1996. (VII. 30.) HM-NM együttes rendelet „A katonai szolgálatra való egészségi alkalmasság elbírálásáról”- már a rendszerváltás korszakában készült.

- A 78/1997 HM határozat létrehozta a Magyar Honvédség Egészségvédelmi Intézetét, majd a jelen kor elvárásaihoz igazítva ezt az alapító okiratot a 98/2005 (HKSZ) HM határozattal módosították. Az intézet egyik alapvetö feladata lett a katonai alkalmassági vizsgálatok elvégzése, a különböző időszakos, szúró-, záró- és egyéb felülvizsgálatok magas szintü szakmai ellátása. A honvédség személyi állomány munkaképességének megőrzése érdekében az alap és alkalmazott tudományok alkalmazása a szürővizsgálatokban öltött testet.

A sorozási alkalmassági vizsgálati rendszer a rendszerváltás óta többszörösen megújult, ennek ellenére kiigazítást igényel. Nem lehet vitatni, hogy az orvostudomány fejlődésének mai üteme mellett minden, a beteg ellátással foglalkozó orvosnak rendszeresen képeznie kell magát. Ez jogi, szakmai és etikai kötelessége minden egészségügyi dolgozónak.

- A 9/2002. (II. 28.) HM-EüM együttes rendelet, A hadkötelezettség alapján teljesítendő katonai szolgálatra és a katonai oktatási intézményi tanulmányokra való egészségi alkalmasság elbírálásáról” rendelkezik. Ezt a 24/2003. (VII. 7.) HM-ESzCsM együttes rendelet módosította.

- A 4/2003. (I. 31.) HM rendelet „A hivatásos és szerződéses katonák egészségi, pszichikai és fizikai alkalmasságának minősítését" szabályozza.

- A 2004. évi CV. törvény „a honvédelemről és a Magyar Honvédségről". Rendkívüli állapot idején, illetve az
Országgyülés külön döntése alapján megelőző védelmi helyzetben a Magyar Köztársaság területén lakóhelylyel rendelkező minden nagykorú, magyar állampolgárságú férfi hadköteles. A katonai nyilvántartásban a személyazonosító adatok, családi állapot és egyéb adatokon túl a szolgálat tervezését és teljesítését befolyásoló adatokat is tartalmaznia kell, úm. katonai szolgálatra való alkalmasságot befolyásoló betegséget, szomatometriai adatot, iskolai tanulmányt, szakképzettséget, foglalkozást, idegen nyelv ismeretet, stb.

- A 7/2006. (III. 21.) HM rendelet „A hivatásos és szerződéses katonai szolgálatra, valamint a katonai oktatási intézményi tanulmányokra való egészségi, pszichikai és fizikai alkalmasság elbírálásáról, továbbá az egészségügyi szabadság, a szolgálatmentesség és a csökkentett napi szolgálati idő engedélyezésének szabályairól” szól.

\section{Összegzés}

- Az egészségügyi alkalmassági vizsgálatnak komplexnek kell lennie minden esetben (csont-ízületi-, kardiovaszkuláris-rendszer, humántipológiai megfelelőség, fizikai- erőnléti állapot)

- A hivatásos, az önkéntes, szerződéses állományra egyformán vonatkozzanak az egészségügyi alkalmassági elöírások.

- A katonai szolgálat sajátosságaiban megjelenhetnek a kor fejlődésével új elemek, új elvárások ehhez adaptáltan kell az alkalmassági vizsgálatokat is elvégezni.

- A megfelelö katona megfelelő szolgálatba, illetve fegyvernemi beosz- 
tásba kerüljön (alkalmassági vizsgálati paraméterek, a személyügyi munka és a fizikai paraméterek alapján kell, hogy a döntés megszülessen, lehetőség szerint a katona elvárásait figyelembe véve).

„Halld meg te, igaz Isten, én beszédemet, Es te, o, vitéz gróf én esküvésemet!

Hazámért kéméllem hogyha életemet,

Ha vigan nem ontom, a, hol köll,

véremet;

Mi vitézül éltünk, vitézül meghaljunk,

Egész ez világnak evvel példát hagyjunk.

Ma mi tisztességet nevünkre szállitunk, Mai nap szépéti minden elmult dolgunk."

\section{Irodalom}

[1] Biblia Ószövetségi és Újszövetségi szentírás, Budapest 2005. Szt. István társulat könyvkiadója, ISBN: 9633616646.

[2] Csirszka J.: A személyiség munkatevékenységének pszichológiája. Akadémia Kiadó, Budapest, 1985.

[3] József I.: A katonai alkalmasság vizsgálat múltja, jelene és egy lehetséges alternatívája. Új Honvédségi szemle, 2002, 124-130.

[4] Klein S.: Munkapszichológia - Gondolat Kiadó, Budapest, 1980.

[5] Kovács P.: Terhelés-, és teljesítmény-élettani mutatók vizsgálata a magyar honvédség és a civil szféra hadrafoghatóság szempontjából érintett területein. $\mathrm{PhD}$ értekezés. Kun L.: Egyetemes testnevelés és sporttörténet, Sport kiadó, Budapest, 1990 alapján.

[6] Mitológiai enciklopédia 11. Gondolat K., Budapest, 1988 p.:235, ISBN: 9632820282.

[7] Nemere István: A Zrínyi család, Anno Kiadó, MMV, ISBN 9633754054.
[8] Popper P.: Az Írás - Az Ószövetség - A Teremtés Könyvétől, Malakiás prófétáig 02004-ISBN 963930896 X. Saxum Kiadó.

[9] Svéd L.: A Magyar Honvédség egészségügyi biztosítása elvének és gyakorlatának változásai, sajátosságai, különös tekintettel a haderő átalakítására, a NATO-ba történő integrálásra, a különböző fegyveres konfliktusok, valamint a békefenntartó, béketeremtő és támogató tevékenységre. 2003, PhD értekezés.

[10] Szabó Cs.: Gondolkodás, KLTE 1995.

[11] Zrínyi M.: „Ne bántsd a magyart! Az török áfium ellen való orvosság”.

[12] Zrínyi M.: Szigeti veszedelem.

[13] 2004. évi CV. törvény a honvédelemről és a Magyar Honvédségről.

[14] http://www.zmne.hu/kulso/mhtt/hadtudomany/2001/3/07/chapter1.htm - Gál Anna: Az emberi igények és a szervezeti követelmények összhangja. Honvédorvosban történő megjelenítéshez.

[15] Az Európa perifériáján megjelenő fenyegetések egyre határozottabb válaszreakciót, ütöképes haderőt és annak folyamatos fejlesztését kívánja meg a fejlett országoktól.

[16] A felgyorsuló és összetetté váló politikai, gazdasági, társadalmi és demográfiai folyamatok kihatnak a haderő felkészítésére és fejlesztésére. A nemzeti haderő legfontosabb és egyben elengedhetetlen pillérei maguk a katonák, akiknek állományba vételét, felkészítését, kiképzését mindenképpen meg kell, hogy előzze egy mindenre kiterjedő alkalmasság vizsgálati folyamat.

[17] A XXI. századi biztonságpolitikai követelmények létfontosságú elemként kezelik a katonai alkalmasság kérdését, hiszen az ország védelme, ill. a NATO-ban vállalt kötelezettségeink magas szintű elvárást támasztanak katonáinkkal szemben. Hazánkban mindig is kulcskérdés volt a honvédelem ügye, ennek értelmében a sorozási alkalmassági vizsgálati rendszer az évszázadok alatt többszörösen megújult, mégis kiigazítást igényel. 
[18] Az új évezred küszöbén az élet minden területén meghatározó befolyással bíró globális verseny az ország biztonságának zálogául szolgáló hadsereggel szemben is komoly elvárásokat támaszt. Minden ember önálló személyiség, többé-kevésbé sajátos adottságokkal, személyiségi vonásokkal, és viselkedési formákkal. Az alkalmasság vizsgálata minden esetben az egész személyre irányul, hogy képes lesz-e a neki kiadott feladat ellátására.

[19] A cikk szakmai elemzéseiből kiderül, hogy az alkalmasság csak potenciálisan állapítható meg, minden a gyakorlatban dől el, azaz hogy a katona az elvárásoknak megfelelően hajtja-e végre a feladatot. Megállapítást nyert az is, hogy az egészségügyi alkalmassági vizsgálatnak komplexnek kell lennie minden esetben, továbbá, hogy a hivatásos, az önkéntes, szerződéses állományra egyformán vonatkozzanak az egészségügyi alkalmassági elöírások.

[20] Napjainkra egyértelművé vált, hogy a katonai szolgálat sajátosságaiban megjelenhetnek a kor fejlődésével új elemek, új elvárások ehhez adaptáltan kell az alkalmassági vizsgálatokat is elvégezni. Mindezen tényezők együttes alkalmazásával biztosítható, hogy a megfelelő katona megfelelő szolgálatba illetve fegyvernemi beosztásba kerüljön.
Col. (ret,) Prof. S. Sandra MD, PhD,

Maj.Gen. I. Kun Szabó,

Brig.Gen. L. Sticz PhD

\section{The suitability of soldiers}

On the eve of a new millenium globalisation has a great effect on all area of life. There is no exception for an army that guaranties the security of the nation. The military competence is handled by the security policy as a crucial part of it in the 21st century since the defence of the country or our nation's requirements in the NATO mean high level of expectations towards our army.

The idea of "the right man in the right place" was born thousands of years ago but the ways of competence-examinations always varied during history. However national defense was a key issue for Hungary. Therefore the system of competence examination during enlistment was renewed many times from the time of our political change but after all there is a need to correct it.

Key-words: globalisation, the capability of soldiers, security policy, monitoring system

Prof. Dr. Sandra Sándor ny. o. ezds. 1134 Budapest, Róberet Károly krt. 44. 